\title{
Testing the potential of enhanced phytoextraction to clean up NORM and heavy metal contaminated soils
}

\author{
H. Vandenhove ${ }^{1}$, L. Duquène ${ }^{1}$, F. Tack ${ }^{2}$, J. Baeten ${ }^{3}$ and J. Wannijn ${ }^{1}$ \\ ${ }^{1}$ Belgian Nuclear Research Centre (SCKCEN), Biosphere Impact Studies, 2400 Mol, Belgium \\ ${ }^{2}$ Ghent University, Laboratory for Analytical Chemistry and Applied Ecochemistry, \\ 9000 Gent, Belgium \\ ${ }^{3}$ Katholieke Hogeschool Kempen, Department of Health-Care and Chemistry, \\ $2440 \mathrm{Geel}$, Belgium
}

\begin{abstract}
A greenhouse experiment was set up to evaluate the potential of enhanced phytoextraction to clean up $U$ and heavy metal contaminated soils. One soil had a naturally high $U$ concentration; the other soil was impacted by the radium extraction industry. Enhancement of solubility and uptake by plants (ryegrass and Indian mustard) was monitored after addition of 5 chemical amendments: citric acid, ammonium citratecitric acid mixture, oxalic acid, EDDS and NTA. Solubilisation and uptake were highly influenced by the amendment applied and soil-plant combinations. For U, citric acid, the ammonium citrate-citric acid mixture or EDDS were most effective in increasing $\mathrm{U}$ uptake. EDDS was most effective in increasing $\mathrm{Cu}$ in mustard and ryegrass and $\mathrm{Pb}$ in ryegrass shoots. For other metals, increase in uptake was limited to at most a factor 5. Percentages annually removed with biomass ranged from $0.0002 \%$ to $1.52 \%$., and were lowest for $\mathrm{U}, \mathrm{Cr}$ and $\mathrm{Pb}$ and highest for $\mathrm{Cd}$. A targeted $10 \%$ reduction in soil contaminant would require 7 years for $\mathrm{Cd}, 35$ and 52 years for $\mathrm{Cu}$ and $\mathrm{Zn}, 203$ and 384 years for $\mathrm{U}$ and $\mathrm{Pb}$ and 9433 years for Cr. Phytoextraction is hence not a feasible technique to decontaminate historically contaminated soils.
\end{abstract}

\section{INTRODUCTION}

Radioactive elements such as $\mathrm{U}, \mathrm{Ra}$ and $\mathrm{Th}$, and non-radioactive elements such as $\mathrm{Cd}, \mathrm{Zn}, \mathrm{Cu}, \mathrm{Ni}$, and As can simultaneously occur at sites contaminated as a result of industrial activities involved in the extraction or processing of raw materials containing naturally occurring radionuclides (NOR) e.g. uranium mining and milling or P-fertilizer industry. Phytoremediation has been proposed as an environmentally friendly approach to manage contaminated soils. Trace element phytoavailability in soils is limiting the applicability of phytoextraction as a remediation technique and increasing the phytoavailable pool of metals in soil is the first prerequisite. In addition, yield should be high.

Several authors tested amendments to enhance uptake of $U$ by plants. Ebbs et al. [1] and Huang et al. [2] studied the role of acidification and chelating agents on the solubilisation of uranium. Of the organic acids tested (acetic acid, citric acid, oxalic acid, malic acid) citric acid was the most effective in increasing uranium in the soil solution. Chelating agents like EDTA and DTPA did not increase uranium solubility significantly. Vandenhove et al. [3] tested the potential to phytoextract uranium from a sandy soil contaminated with low levels of U. Ryegrass, Indian mustard and Amaranthus retroflexus were used as test plants. The addition of citric acid $\left(25 \mathrm{mmol} \mathrm{kg}^{-1}\right)$ one week before harvest increased uranium uptake up to 500-fold. Plants growth was, however, seriously hampered after citric acid addition. Shahandeh and Hossner [4] screened U uptake by sunflower and Indian mustard after addition of chelates (CDTA, DTPA, EDTA and HEDTA) or organic acids (oxalic and citric acid). Oxalic acid and citric acid were equally effective in increasing U-uptake (up to 150-fold). Addition of chelates had little effect on U shoot concentrations. Moreover, mentioned chelates are little biodegradable, can hence promote leaching from soil and some heavy metal-chelate complexes can be toxic for plants [5]. In recent years, the use of easily biodegradable chelating agents such as NTA (nitrilotriacetate) and EDDS 
(S,S-ethylenediaminedisuccinic acid) has been proposed to enhance uptake of heavy metals. Grčman et al. [5] reported 102-, 4.7- and 3.5-fold increases in phytoaccumulation of, respectively, $\mathrm{Pb}, \mathrm{Zn}$, and $\mathrm{Cd}$ in cabbage after application of $10 \mathrm{mmol}$ EDDS per $\mathrm{kg}$ soil. Luo et al. [6] found that EDDS was more effective in increasing uptake of $\mathrm{Cu}$ (45 to 135-fold) and Zn than EDTA. Quartacci et al. [7] observed a 2- to 3-fold increase of $\mathrm{Cd}, \mathrm{Cu}, \mathrm{Pb}$ and $\mathrm{Zn}$ concentrations in shoots of Indian mustard after application of 5 mmol NTA kg-1 soil. Shen et al. [8] reported that $1.5 \mathrm{mmol} \mathrm{kg}^{-1}$ soil NTA increased Pb concentration in soil solution from 15.2 to around $390 \mathrm{mg} \mathrm{L}^{-1}$ and was 3 -fold more efficient than citric acid. NTA was also more effective than citric acid for increasing $\mathrm{Pb}$ accumulation in cabbage shoots.

The aim of present study is to test the efficiency of three organic acids (citric acid, mixture of citric acid-ammonium citrate and oxalic acid) and two chelates (EDDS and NTA) in increasing the phytoextraction potential of $\mathrm{U}$ and a heavy metals $(\mathrm{Cd}, \mathrm{Cr}, \mathrm{Cu}, \mathrm{Pb}, \mathrm{Zn})$ from soils with enhanced NOR levels. Citric acid and oxalic acid were selected because of their reported efficiency in increasing $\mathrm{U}$ uptake; the citric acid-ammonium citrate since citrate addition often negatively affected plant performance; EDDS and NTA for their reported effectiveness in mobilising heavy metals.

\section{MATERIALS AND METHODS}

\subsection{Soils and soil analysis}

Two Belgian soils with different uranium contamination history were used in this study. The Bankloop soil (BK) was impacted by a former radium extraction industry. The Bioul soil (BI, S. Belgium) has high natural background levels of $U$ and $U$ and heavy metal availability is very low.

Soils were air-dried, sieved and thoroughly characterised. The total U and HM content was measured from finely ground and calcinated sub-samples after fusion by ICP-MS. After three weeks incubation (50\% WHC) and three days before sowing, soils were transferred to $1 \mathrm{~L}$ polyethylene recipients. In each recipient, a rhizon soil moisture sampler was inserted and soil solution was sampled the day of sowing, one day before addition of the amendments and after harvest. Soil solution was analysed for U and HM concentration with ICP-MS.

\subsection{Plant culture and application of amendments}

Indian mustard (Brassica juncea cv. Vitasso) and ryegrass (Lolium perenne cv. Melvina) seeds were sown on top of the moist incubated soils. In total 72 containers were prepared $(2$ soils, 2 plants, 5 amendments and control, 3 replicates $)$ and kept under greenhouse conditions $\left(27^{\circ} \mathrm{C} / 17^{\circ} \mathrm{C}, 12 \mathrm{~h} / 12 \mathrm{~h}\right.$, $300 \mu \mathrm{mol}$ photons $\mathrm{m}^{-2} \mathrm{~s}^{-1}$ ). Throughout plant growth, soil moisture was controlled and adjusted with demineralised water by weighing every second day. After four weeks of plant growth, containers were amended with $5 \mathrm{mmol} \mathrm{kg} \mathrm{kg}^{-1}$ soil dry weight of one of the following amendments: citric acid, an $\mathrm{NH}_{4}$-citrate/citric acid mixture $\left(2.5 \mathrm{mmol} \mathrm{kg}{ }^{-1}\right.$ of each), oxalic acid, EDDS or NTA. The amendment was applied on the soil surface.

Plants were harvested two weeks after amendment, except for Indian mustard grown on BK soil and treated with citric acid and EDDS which was harvested after four and eight days, respectively. Shoot dry weight (DW) was recorded and plant digests were analysed for total $\mathrm{U}$ and $\mathrm{Cd}, \mathrm{Cr}, \mathrm{Cu}, \mathrm{Pb}, \mathrm{Zn}$ content with ICP-MS.

\section{RESULTS AND DISCUSSION}

\subsection{Effect of plant growth and amendments on $U$ and heavy metal solubilisation}

If we compare the concentrations in soil solution before sowing and before amendment (after one month of plant growth), we observe a more than 20 -fold increase in U concentration in the soil solution on the 
BK soil and this when cultivated with either of the plants (Table 1). On the BI soil there is hardly any increase in soil solution concentration induced by plant growth.

On the BK soil, highest U concentrations in the soil solution were obtained after amendment with citric acid, followed by EDDS. On the BI soil, citric acid and the ammonium citrate-citric acid mixture were most effective resulting in increased soil solution concentrations compared to the control.

Table 1. Total $\mathrm{U}$ concentration $\left(\mathrm{mg} \mathrm{kg}^{-1}\right)$ and soil solution concentration of $\mathrm{U}\left(\mu \mathrm{g} \mathrm{L}^{-1}\right)$ of Bankloop (BK) and Bioul (BI) soil before sowing, before amendment (after 1 month of plant growth) and at harvest. SD between brackets. $\mathrm{N}=3$.

\begin{tabular}{|c|c|c|c|c|c|c|c|c|c|c|}
\hline & \multirow[b]{3}{*}{ Soil } & \multirow[b]{3}{*}{$\begin{array}{l}\text { Total } \\
\mathrm{mg} \mathrm{kg}^{-1}\end{array}$} & \multicolumn{8}{|c|}{ Soil solution, $\mu \mathrm{g} \mathrm{L}^{-1}$} \\
\hline & & & \multirow{2}{*}{$\begin{array}{l}\text { Before } \\
\text { sowing }\end{array}$} & \multirow{2}{*}{$\begin{array}{c}\text { Before } \\
\text { amendment }\end{array}$} & \multicolumn{6}{|c|}{ At harvest } \\
\hline & & & & & Control & $\begin{array}{l}\text { Citric } \\
\text { acid }\end{array}$ & $\begin{array}{l}\text { Citric acid- } \\
\mathrm{NH}_{4} \text { citr. }\end{array}$ & $\begin{array}{c}\text { Oxalic } \\
\text { acid }\end{array}$ & EDDS & NTA \\
\hline \multirow[t]{2}{*}{ Mustard } & BK & $14(1)$ & $11(1)$ & $211(43)$ & $226(64)$ & $4100(10)$ & $851(267)$ & $448(100)$ & $1900(287)$ & $934(394)$ \\
\hline & BI & $41(1)$ & $2(0)$ & 4() & $10(6)$ & $5(1)$ & $5(1)$ & $3(0)$ & $3(0)$ & $10(2)$ \\
\hline \multirow[t]{2}{*}{ Ryegrass } & BK & $14(1)$ & 11(1) & 253() & $383(146)$ & $2015(641)$ & $1031(780)$ & $546(178)$ & $1418(515)$ & $518(114)$ \\
\hline & BI & $41(1)$ & $2(0)$ & 4() & $2(0)$ & $8(3)$ & 41() & $2(0)$ & $6(1)$ & $7(2)$ \\
\hline
\end{tabular}

Table 2. Total concentration $\left(\mathrm{mg} \mathrm{kg}^{-1}\right)$ and soil solution concentration of selected heavy metals $\left(\mu \mathrm{gL}^{-1}\right)$ for Bankloop and Bioul soil before sowing, before amendment (after 1 month of plant growth with Indian mustard or ryegrass) and at harvest (only results for most effective amendment). SD between brackets. $\mathrm{N}=3$.

\begin{tabular}{|c|c|c|c|c|c|c|}
\hline \multirow[b]{3}{*}{ Bankloop } & \multirow{3}{*}{$\begin{array}{c}\text { Total } \\
\mathrm{mg} \mathrm{kg}^{-1}\end{array}$} & \multicolumn{5}{|c|}{ Soil solution, $\mu \mathrm{g} \mathrm{L}^{-1}$} \\
\hline & & \multirow{2}{*}{$\begin{array}{l}\text { Before } \\
\text { sowing }\end{array}$} & \multicolumn{2}{|c|}{ Before amendment } & \multicolumn{2}{|c|}{ At harvest } \\
\hline & & & Mustard & Ryegrass & Mustard & Ryegrass \\
\hline $\mathrm{Cd}$ & $1(1)$ & $7(2)$ & $6(1)$ & $5(1)$ & 1215(472) NTA & 718(237) NTA \\
\hline $\mathrm{Cr}$ & $467(16)$ & $<\mathrm{DL}$ & $<50$ & $<50$ & 464(738) NTA & 348(171) EDDS \\
\hline $\mathrm{Cu}$ & $372(16)$ & $239(4)$ & $426(128)$ & $343(51)$ & 561700(132300) EDDS & 711410(120500) EDDS \\
\hline $\mathrm{Pb}$ & $254(15)$ & $<\mathrm{DL}$ & $<50$ & $<50$ & 18813(7103) NTA & 8326(3827) NTA \\
\hline $\mathrm{Zn}$ & $704(71)$ & $379(13)$ & $352(66)$ & $457(94)$ & 406200(119700) NTA & 276600(38100) NTA \\
\hline \multicolumn{7}{|l|}{ Bioul } \\
\hline $\mathrm{Cd}$ & $2(0)$ & $<\mathrm{DL}$ & $<5$ & $<5$ & 319(49) NTA & 282(24) NTA \\
\hline $\mathrm{Cr}$ & $209(16)$ & $<\mathrm{DL}$ & $<50$ & $<50$ & 20(4) EDDS & 28(4) EDDS \\
\hline $\mathrm{Cu}$ & $430(8)$ & $92(2)$ & $185(14)$ & $163(27)$ & $173900(21600)$ NTA & 127800(9700) EDDS \\
\hline $\mathrm{Pb}$ & $35(10)$ & $<\mathrm{DL}$ & $<50$ & $<50$ & 92(33) NTA & 106(48) NTA \\
\hline $\mathrm{Zn}$ & $151(6)$ & $<\mathrm{DL}$ & $79(1)$ & $84(14)$ & 8496(504) NTA & 7056(1077) NTA \\
\hline
\end{tabular}

$\mathrm{Cu}$ concentration increased up to 2-fold on BK and BI, and $\mathrm{Zn}$ 17-fold on BI following plant growth (Table 2). There was no difference between concentrations before sowing and before amendment for $\mathrm{Cd}, \mathrm{Cr}$ and $\mathrm{Pb}$ on both soils and for $\mathrm{Zn}$ on BK. Citric acid was most effective in solubilising Cr. For $\mathrm{Cd}, \mathrm{Zn}$ and $\mathrm{Pb}$, NTA was most effective (180-650-fold increases) and for Cu EDDS (1240-1570 fold increase).

\subsection{Effect of amendments on plant dry weight}

Dry weight was always higher on BI soil than on BK soil and always higher for Indian mustard than for ryegrass, except for EDDS treated soils. Ryegrass shoot DW was not affected by amendment (figure 1a). Treatment with EDDS significantly decreased growth of Indian mustard on both soils. Indian mustard plants only survived on one out of three containers citric acid amended BK soil. The three other amendments had no detrimental effect on DW production. Several authors have reported negative effects of citric acid on yield and survival of plants [3, 4, 9]. Luo et al. [6] reported a shoot DW loss of 48 and $39 \%$ for corn and bean, respectively, after application of $5 \mathrm{mmol} \mathrm{kg}^{-1}$ EDDS to an alkaline sandy soil. 


\subsection{Efficiency of amendments to enhance phytoextraction}

On BK soil, EDDS was most effective in increasing U uptake by Indian mustard (factor 9.4) and citric acid (factor 5.9) and EDDS (factor 5.5) in increasing U uptake by ryegrass. On BI soil, citric acid and the citric acid/ammonium citrate mixture were most effective in increasing $\mathrm{U}$ uptake by mustard (5.6 and 4.6 fold) and ryegrass (2.4 and 2.6-fold) (Figure 1b). After addition of $20-25 \mathrm{mmol} \mathrm{kg}^{-1}$ soil citric acid, Vandenhove et al. [3] and Shahandeh and Hossner [4] found a 150-fold increase in U uptake by Indian mustard and sunflower, respectively, for U spiked soils.
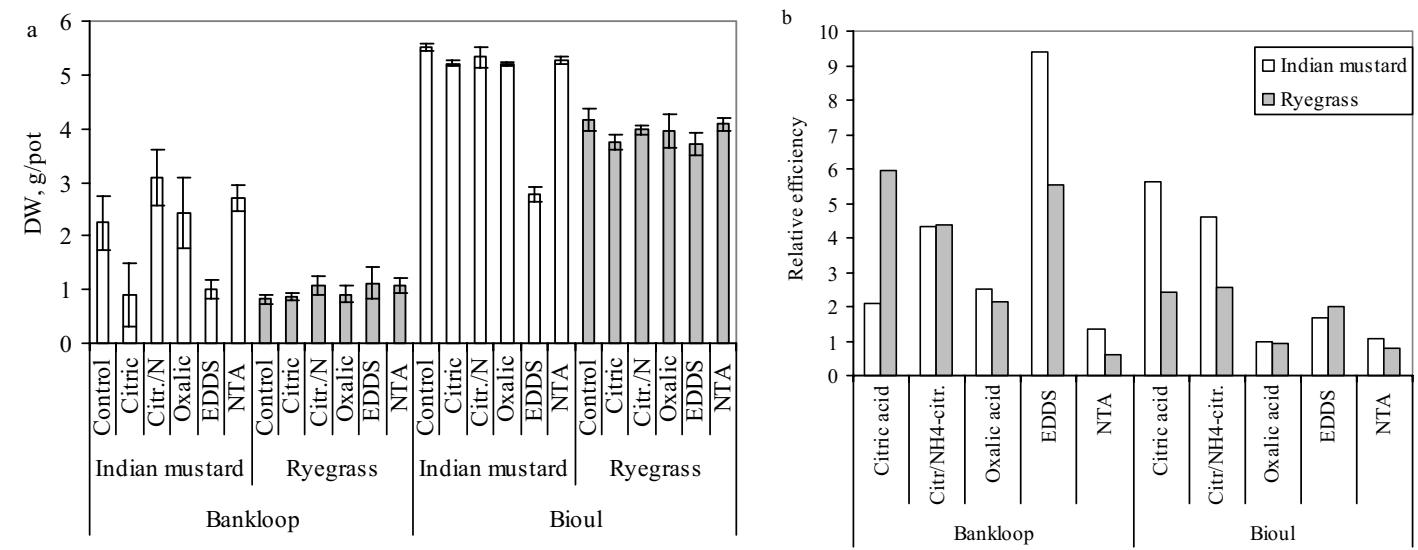

Figure 1. (a) Shoot dry weight of Indian mustard and ryegrass on Bankloop and Bioul soils after application of amendments; (b) Relative efficiency of amendments in increasing U shoot uptake compared to the respective controls.

On BK soil application of EDDS resulted in 34 and 37-fold increases in concentration of $\mathrm{Pb}$ and $\mathrm{Cu}$ in mustard shoots (Figures 2a,b). For other metals, the increase of plant uptake was limited to at most a factor 5. On the BI soil increase in heavy metal uptake following amendment was hardly significant. Ryegrass generally extracted less $U$ and heavy metals than Indian mustard.

Amendments resulted in a more important increase in pore water concentrations than uptake. There was no relation between $\mathrm{U}$ or HM soil solution concentrations observed after amendment and plant uptake. Phytoextraction efficiency can hence not be predicted from soil tests.
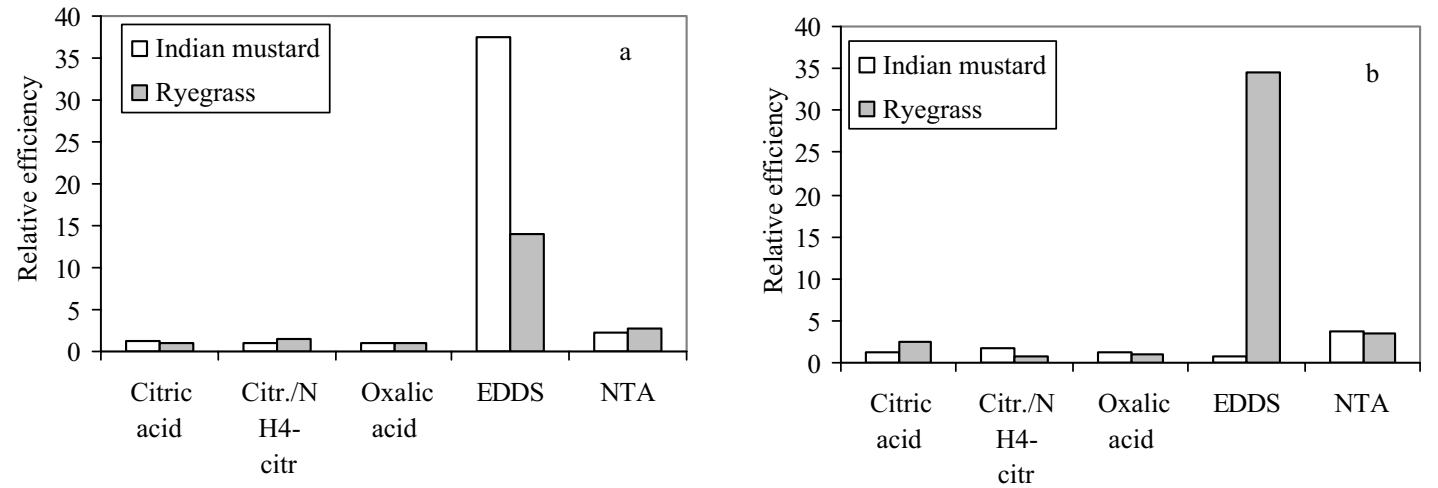

Figure 2. Relative efficiency of amendments in increasing $\mathrm{Cu}$ (a) or $\mathrm{Pb}$ (b) shoot uptake on Bankloop soils compared to the respective controls. 


\subsection{Phytoextraction efficiency of $U$ and $\mathrm{HM}$}

The removal of a contaminant from soil with the harvested biomass (in $\mathrm{mg} \mathrm{pot}^{-1}$ or kg ha ${ }^{-1}$ ), is the product of the concentration in the plant $\left(\mathrm{C}_{\text {plant }}\right.$, in $\left.\mathrm{g} \mathrm{kg}^{-1}\right)$ and the yield of the harvested biomass $\left(\mathrm{g} \mathrm{pot}^{-1}\right.$ or $\left.\mathrm{tha}^{-1}\right)$. The percentage annual reduction in soil activity is given by

$$
\text { Annual removal }(\%)=\frac{C_{\text {plant }} \times \text { Yield }}{C_{\text {soil }} \times W_{\text {soil }}} * 100
$$

with $\mathrm{C}_{\text {soil }}$ the concentration of contaminant in the soil $\left(\mathrm{g} \mathrm{kg}^{-1}\right)$ and $\mathrm{W}_{\text {soil }}$ the weight of the contaminated soil layer $\left(\mathrm{g} \mathrm{pot}^{-1}\right.$ or ton ha $\left.{ }^{-1}\right)$.

Percentages removed with the plant biomass in this experiment were small, ranging from $0.0001 \%$ to $1.52 \%$. Removal percentages were generally lower for BI than for BK despite the lower yield on BK and were generally lowest for $\mathrm{U}, \mathrm{Cr}$ and $\mathrm{Pb}$ and highest for $\mathrm{Cd}$. Since duration of the pot experiment (6 weeks) was short compared to the duration of a full growing season, final yield and hence annual removal might in practice be higher. Phytoextraction requires several years and the future trend in radionuclide concentration in the soil $\left(\mathrm{C}_{\text {soil, } \mathrm{t}}\right)$ can be calculated according:

$$
\mathrm{C}_{\text {soil }, \mathrm{t}}=C_{\text {soil }}=0 \text { exp }\left\{-\frac{C_{\text {plant }} \times \text { yield }}{C_{\text {soil }} \times W_{\text {soil }}}\right\} t
$$

This equation also allows calculating the number of years required to attain a targeted reduction in soil concentration. With the optimal scenario for $U$ extraction (BK soil, Indian mustard and EDDS), only $0.05 \%$ of the total soil $\mathrm{U}$ could be annually extracted. If one would target only a $10 \%$ reduction in total soil U, still 203 years of phytoextraction would be required (Table 2). A $10 \%$ reduction in $\mathrm{Cd}$ concentration is predicted to be achieved in 7 years on BK soil but the most effective amendment (NTA) is hardly more effective than the control (9 years required). For $\mathrm{Cu}$ and $\mathrm{Zn}$, respectively 35 and 52 years are required to remove $10 \%$ of the initial activity of BK soil with mustard biomass following EDDS amendment. When NTA was found the most effective amendment, effectiveness of EDDS was generally comparable to maximally a factor 2 lower. For all other scenarios substantially more years were required to remove only $10 \%$ of the metal - from about 90 to as much as 45000 years for $\mathrm{Cr}$ on BI soil.

Table 3. Years required to remove $10 \%$ of total $U$ and heavy metals from Bankloop soil through phytoextraction.

\begin{tabular}{l|cccc}
\hline Metal & \multicolumn{2}{|c}{ Indian mustard } & \multicolumn{2}{c}{ Ryegrass } \\
\hline \multirow{3}{*}{$\mathrm{U}$} & Amendment & Years & Amendment & Years \\
\cline { 2 - 5 } $\mathrm{Cd}$ & EDDS & 203 & Citric acid & 508 \\
$\mathrm{Cr}$ & NTA & 7 & NTA & 29 \\
$\mathrm{Cu}$ & NTA & 12601 & Citric acid & 9433 \\
$\mathrm{~Pb}$ & EDDS & 35 & EDDS & 86 \\
$\mathrm{Zn}$ & EDDS & 384 & NTA & 3912 \\
& EDDS/NTA & 52 & NTA & 110 \\
\hline
\end{tabular}

\section{CONCLUSIONS}

Present study showed that $U$ and heavy metal phytoextraction potential was highly dependent on soil-crop-amendment combinations. There was no relation between the amount of $U$ or heavy metals solubilised after application of the amendment and the $U$ taken up by the plants. Therefore, soil tests cannot be used to screen and predict the phytoextraction efficiency of amendments.

With 7 to 9433 years required to extract $10 \%$ of the metals present, enhanced phytoextraction seems hardly feasible for soils with historic contamination with $U$ and heavy metal levels. For the soil with naturally high levels phytoextraction efficiency was even lower. From our results we can however 
conclude that when faced with a multipollution scenario, Indian mustard and EDDS are very likely the best plant-amendment combination for maximal phytoextraction of a mixture of metals.

\section{References}

[1] Ebbs S.D., Norvell W.A. and Kochian L.V., J. Environ. Qual. 27 (1998) 1486-1494.

[2] Huang J.W., Blaylock M.J., Kapulnik Y. and Ensley B.D., Environ. Sci. Technol. 32 (1998) 2004-2008.

[3] Vandenhove H., Van Hees M., and Van Winckel S., Int. J. Phytorem. 3 (2001) 301-320.

[4] Shahandeh H., and Hossner L.R., Soil Sci. 167 (2002) 269-280.

[5] Grěman H., Vodnik D., Velikonja-Bolta S. and Lestan D., J. Environ. Qual. 32 (2003) 500-506.

[6] Luo, C., Shen, Z. and Li X., Chemosphere 59 (2005) 1-11.

[7] Quartacci M.F., Argilla A., Baker A.J.M. and Navari-Izzo F., Chemosphere 63 (2006) 918-925.

[8] Shen Z.G., Li X.D., Wang C.C., Chen H.M. and Chua H., J. Environ. Qual. 31 (2002) 1893-1900.

[9] Meers E., Hopgood M., Lesage E., Vervaeke, P., Tack F.M.G. and Verloo M., Int. J. Phytorem. 6 (2004) 95-109. 